\begin{tabular}{|ll|}
\hline & $\begin{array}{l}\text { International Journal of Advanced Engineering, Management and } \\
\text { Science (IJAEMS) } \\
\text { INF }\end{array}$ \\
Peer-Reviewed Journal \\
ISSN: 2454-1311 / Vol-7, Issue-11; Nov, 2021 \\
Journal Home Page: https://ijaems.com/ \\
Article DOI: https://dx.doi.org/10.22161/ijaems.711.2
\end{tabular}

\title{
Development and Validation of a Scale for Measuring Internal Auditing Effectiveness in Tunisian Companies
}

\author{
Hella Dellai, Nadia Slimene
}

Higher Institute of Finance and Taxation Sousse, University of Sousse, Tunisia.

Received: 09 Oct 2021; Received in revised form: 15 Nov 2021; Accepted: 22 Nov 2021; Available online: 29 Nov 2021

\begin{abstract}
The purpose of the current study is to develop and validate a multidimensional scale for measuring internal auditing effectiveness (IAE) in Tunisia. The authors' methodological approach is based on both qualitative and quantitative methodologies. The qualitative technique was used to generate scale items to measure IAE and the quantitative technique was utilised to test and validate the scale. The sample includes 148 chief internal auditors from Tunisian companies. Data were divided in half. First half was utilised for exploratory factor analysis (EFA) and the second half of the data were utilised to run confirmatory factor analysis (CFA). The study found that IAE is a three-dimensional construct (internal audit process, output of internal audit and impact of internal audit) which is consisted of 16 items. This reliable and valid scale offers a practical instrument to measure IAE that very interesting to managers and external auditors.
\end{abstract}

Keywords - Internal auditing, Effectiveness, Exploratory factor analysis, Confirmatory factor analysis, Tunisia.

\section{INTRODUCTION}

In recent years, internal audit plays an increasingly important role in good corporate governance. The internal audit function is essential to aid organizations in achieving their goals by improving the performance of the internal control and risk management process (Gramling et al., 2004; Radu, 2012; Regoliosi \& D'Eri, 2014; Vadasi et al., 2019). Consequently, internal audit should be so effective that it meets the goals of their function. Effectiveness suits the main feature of the internal audit function, so it is critical to find an adequate instrument for evaluating the effectiveness of the internal audit in organizations.

The purpose of this study is to develop a scale of measurement of internal auditing effectiveness. This brings us to ask our main question as follows: what are the principals' dimensions of the construct of internal auditing effectiveness in Tunisia? Our methodological approach is based on the approach of Churchill (1979).

To date, there has been no consensus among researchers on the measurement of internal auditing effectiveness due to the complexity to observe this concept. Previous studies have attempted to assess the effectiveness of the internal audit function through surveys of the managers' satisfaction (Cohen \& Sayag, 2010), the level of compliance of internal audit work with international internal auditing standards (Al-Twaijry et al., 2003), and the percentage of internal audit recommendations implemented by auditees (Arena \& Azzone, 2009). Nevertheless, these measures suffer from certain limits, so they cannot effectively reflect the ability of the internal audit to achieve their objectives.

Our study makes important contributions. First, the study extends the existing literature by developing and validating an instrument to measure the internal auditing effectiveness in the Tunisian context. Second, the present study furthers the understanding of factors improving the effectiveness of internal audit function. Lastly, our study offers managers, audit committees, and external auditors an instrument to measure the level of internal auditing effectiveness in Tunisian companies.

The remainder of this paper is organized as follows: Section 2 presents an overview of the literature review of the effectiveness of the internal audit. Section 3 exposes 
the research methodology. Section 4 presents the results. Section 5 concludes the paper.

\section{LITERATURE REVIEW}

The review of the literature presented below provides an overview of the concept of internal auditing effectiveness.

\subsection{Definition and objectives of internal audit}

According to the definition of internal auditing in the IIA's International Professional Practices Framework (IPPF), internal auditing is an independent, objective assurance and consulting activity designed to add value and improve an organization's operations. It helps an organization accomplish its objectives by bringing a systematic, disciplined approach to evaluate and improve the effectiveness of risk management, control, and governance processes.

Indeed, the fundamental goal of internal audit is to add value and improve an organization's operations and processes (IIA, 1999). Furthermore, Dittenhofer (2001) defined internal auditing effectiveness as the ability of the internal audit function to achieve its objectives.

In essence, an effective internal audit function should contribute to the creation of the added value for the company by improving the effectiveness of risk management, control, and governance processes (Mihret et al., 2010; Erasmus \& Coetzee, 2018; Alzeban, 2020; Hazaea et al., 2020).

In this context, Al-Twaijry et al. (2003), Spira and Page (2003), and Botha and Wilkinson (2019) showed that internal auditing can add value by helping companies to achieve their economic objectives through their involvement in the risk management system and the implementation of their recommendations by the top management. Furthermore, Eden and Moriah (1996) found that the performance of bank branches in Israel significantly improved during the six months following the implementation of internal audit. In a similar study, Salehi et al. (2013) found a significant positive relationship between the existence of an internal audit function and the performance of private banks in Iran.

Octavia (2013) showed that the internal audit function has a significant positive impact on the performance of Indonesian companies in difficulty. Moreover, he stated that every organization needs an internal audit function that can add value to it. In the same vein, Radu (2012) suggested that an efficient internal audit function is supposed to be a tool to assist management in fulfilling its governance responsibilities and that good governance, in turn, helps align the stakeholders' interests and improve the company's performance.
A study conducted by Alzeban (2021) on 212 listed UK companies showed that the implementation of internal audit recommendations drives higher firm performance. A further study by Jiang and al. (2020) shed light on the value added by the internal audit function. The results of this study indicated that whether operations-related services provided by the internal audit function bring economic benefits to firms.

\subsection{Roles of internal audit}

Over the past decade, the role of internal auditing has evolved significantly from a traditional financial controlbased audit to value creation and advisory role (Héroux \& Fortin, 2013). In what follows, we will present the main roles of internal audit.

Traditional role of internal audit: Traditionally, the internal auditor has been responsible for areas such as risk, financial reporting, and regulatory compliance issues. In 2002, the Security and Exchange Commission stated that internal auditing has become essential for the prevention of fraud and the preparation of relevant financial statements. In this context, several studies have shown that an effective internal auditing activity improves the quality of financial reporting, fights against fraud and money laundering, and mitigates the risk of accounting manipulations (Cohen et al., 2004 ; DeZoort \& Harrison, 2008 ; Gras-Gil et al., 2012 ; Naheem, 2016 ; Hazami, 2019 ; Alzoubi, 2019; Alazzabi et al., 2020).

Coram et al. (2008) found that in Australia and New Zealand, organizations with an internal audit function are more likely to detect and disclose fraud and misappropriation of assets than other organizations. Moreover, Agbejule and Jokipii (2009) asserted that internal auditing contributes to the improvement of the performance of Finnish companies by reducing the waste of resources and the opportunities for fraud and corruption that can adversely affect the company. Prawitt et al. (2009) and Garcia et al. (2012) found a negative association between the quality of internal audit and the level of earnings management in companies listed on the NYSE and the Madrid stock exchange, respectively.

In Hong Kong, Law (2011) found a low level of fraud in organizations with an effective internal audit function. In addition, Omar and Abu Bakar (2012) revealed that internal audit is the second most important mechanism in the fight against fraud in companies listed on the Malaysian stock exchange. Moreover, Kabuye et al. (2017) found that objective and competent internal auditors are more likely to perform activities that reduce fraud risk in financial firms in Uganda. Additionally, Ghaleb et al. (2020) indicated that the IAF plays an essential role in reducing real earnings management practices in the 
Malaysian market. The study's findings of Albawwat et al. (2021) showed that the effectiveness of the internal audit function positively impacts the quality of financial reporting in Jordanian listed companies.

Value-added role of internal audit: After corporate accounting scandals that occurred in the 2000-2002 period, internal audit responsibilities have expanded to respond to the organization's needs to achieve its objectives. Indeed, internal audit should support strategic business objectives through the assessment and improvement of risk management, control and governance processes (Carcello et al., 2005; Sarens, 2009; Coetzee, 2016; Ismael \& Roberts, 2018; Vadasi et al., 2019).

In this context, several studies have highlighted the importance of the new role of internal audit. For example, Mohammad Zadeh et al. (2012) showed that internal auditing increases the effectiveness of the internal control process in 337 companies listed on the Tehran Stock Exchange. Furthermore, a study by Sarens and De Beelde (2006) indicated that internal audit plays a crucial role in improving the risk management process in the United States and Belgium. However, internal auditors in the United States are more interested in the evaluation of the internal control system because of the SOX requirements for the review of internal control, whereas in Belgium, internal auditors focus more on the improvement of the risk management system.

On the other hand, Arena and Azzone (2009) found that the effectiveness of internal audit is significantly and positively related to the involvement of internal auditors in the risk management in the Italian companies. As for Oussii and Taktak (2018), they found that the quality of internal control has significantly improved due to the competence of the internal audit function in 59 companies listed on the Tunis Stock Exchange.

\subsection{Measures of internal auditing effectiveness}

Previous researches have distinguished three approaches to measure the effectiveness of the internal audit: process measures, output measures and outcome measures (Arena \& Azzone, 2009).

Process measures: This approach is based on the evaluation of the quality of internal auditing procedures, such as the level of compliance with international internal auditing standards (Glazer \& Jaenike, 1980; Anderson, 1983), and the ability to plan and execute audit missions (Ziegenfuss, 2000b).

In this regard, Al-Twaijry et al. (2003) considered the level of compliance of internal audit work with international internal auditing standards as the most important measure of the effectiveness of internal audit. In addition, Soh and
Bennie (2011) found that the comparison between the audit performed and the audit planned is one of the most used indicators to measure the effectiveness of internal auditing in the Australian context.

Though this approach was used frequently in the previous literature, it suffers from a major limitation as it is based on the on the hypothesis that the internal audit function is effective if its procedures are performed properly, without taking into account the needs of the stakeholders of the company (Lampe \& Sutton, 1994).

Output measures: Output measures reflect the ability of internal auditing to respond to auditees' needs. In this approach, three important measures have been used in previous studies, namely: (1) the auditee satisfaction survey, (2) the percentage of recommendations that are implemented, and (3) the delay to issue the final internal audit report (Ziegenfuss, 2000a 2000b; Frigo, 2002; Arena \& Azzone, 2009; Cohen \& Savag, 2010; Erasmus \& Coetzee, 2018; Farkas et al., 2019).

Although the auditees' satisfaction survey and the rate of implementation of internal audit recommendations have been considered by the Chief of Internal Auditor as the most suitable to evaluate internal auditing effectiveness, many inherent difficulties have been involved at these measures (Salierno, 2000). In fact, the auditee satisfaction survey is based on subjective evaluations from stakeholder (audit committee, board, management). Moreover, the implementation of internal audit recommendations is partially beyond internal auditing control.

Outcome measures: Outcomes measures consist in assessing the impact of the internal audit activities on the organization's processes (Mihret et al., 2010). According to this approach, Dittenhofer (2001) suggested measuring the effectiveness of internal audit in three steps. The first step identifies the auditee's objectives, the second establishes the criteria that could justify the achievement of the identified objectives, and the third step consists in using the established criteria to determine the degree of achievement of the auditees' objectives.

Although this measure is potentially interesting, it seems to be a conceptually difficult method to apply. In fact, it is not so easy to measure the impact of the internal audit function on organizational processes because there is a delay between the times when a certain corrective actions are taken and when their impacts are comprehensible (Balzan \& Baldacchino, 2007).

\section{RESEARCH DESIGN}

Until our days, there is no generally acknowledged measure for the effectiveness of the internal audit. 
Previous researches have been limited to using a single measure that reflects either the quality of the internal audit process or the ability of the internal audit function to meet the expectations of its stakeholders. For this, we rely on the paradigm of Churchill (1979) to develop a scale that takes into account the main dimensions of the effectiveness of internal audit.

\subsection{Item generation}

In order to generate items for the construct, we adopted two procedures. In the first phase, based on a wide-ranging literature review and the international internal standards for internal audit, we identified 49 items and three dimensions of the construct of internal auditing effectiveness, namely process of internal audit (1), output of internal audit (2) and impact of internal audit (3).
Consistent with Nunnally and Bernstein (1994), this stage allows us to generate initial items for the construct and also to produce the content validity.

In the second phase, we conducted 9 interviews with Chief Internal Auditors (CIA) to purify our initial items. The respondents were members of the IIA-Tunisia, had a higher level of education, and more than 5 years' experience in internal audit.

Respondents were asked to retain statements that reflect the construct of the effectiveness of internal audit and delete any ambiguous statements. Subsequently, 25 items were removed at this stage. Finally, a total of 24 items were retained. The dimensions and items for the scale are shown in Table 1.

Table1: Initial item pool of internal auditing effectiveness

\begin{tabular}{lll}
\hline Dimensions & Items & Source/Support \\
\hline $\begin{array}{l}\text { Internal audit } \\
\text { process }\end{array}$ & $\begin{array}{ll}\text { EAI 1- Internal audit (IA) is performed in accordance with } \\
\text { international standards for the professional practice of internal } \\
\text { auditing. }\end{array}$ & Al-Twaijry et al. (2003)
\end{tabular}

EAI 2- IA is performed in accordance with the recommended

Al-Twaijry et al. (2003) guidance.

EAI 3- The chief internal auditor (CIA) takes into account

Ziegenfuss (2000b) expectations of senior management and board of directors when developing the internal audit plan.

EAI 4- The CIA takes into account company's environment when developing the internal audit plan.

EAI 5- The CIA develops a risk-based audit plan.

Ziegenfuss (2000b)

EAI 6- The CIA performs almost all of the annual internal audit plan.

Ziegenfuss (2000b)

Ziegenfuss (2000b)

Internal audit outputs

Impact of internal audit
EAI 7- The CIA ensures that recommendations of internal auditing provide corrective actions for the problems identified.

EAI 8- The level of implementation of internal audit recommendations is high.

EAI 9- The CIA verifies regularly the level of implementation of internal audit recommendations by management.

EAI 10- The CIA communicates the results of internal audit to senior management and board of directors in a timely manner.

EAI 11- Time delay between the end of the mission and the dissemination of the report is short.

EAI 12- IA assesses internal controls deficiencies.

EAI 13- IA assesses the effectiveness of the system of control related to the reliability and integrity of financial and operational information.

EAI 14-IA assesses the effectiveness of the system of control related to the effectiveness and efficiency of operations and programs.
Arena and Azzone (2009)

Arena and Azzone (2009)

Arena and Azzone (2009)

Arena and Azzone (2009)

Ziegenfuss (2000a)

Internal Audit Standards

Internal Audit Standards

Internal Audit Standards 
EAI 15- IA assesses the effectiveness of the system of control related to the asset protection.

EAI 16- IA assesses the effectiveness of the system of control related to compliance with laws. Regulations, procedures and contracts.

EAI 17- IA contributes to improving the internal control process.

EAI 18- IA ensures that the organization's objectives are consistent with the internal audit missions.

EAI 19- IA ensures that the risk treatment methods are appropriate and in line with the risk appetite of the organization.

EAI 20- IA assesses the possible frauds and how risk of fraud is managed by the organization.

EAI 21- IA contributes to improving the risk management process.

EAI 22- IA assesses the design, implementation and effectiveness of the organization's programs and activities related to ethics

EAI 23- IA assesses whether the organization's information systems supports the organization's strategy and goals.

EAI 24- IA contributes to improving the corporate governance process.
Internal Audit Standards

Internal Audit Standards

Internal Audit Standards; Dittenhofer (2001); Cohen and Savag (2010)

Internal Audit Standards

Internal Audit Standards

Internal Audit Standards

Internal Audit Standards; Dittenhofer (2001); Cohen and Savag (2010)

Internal Audit Standards

Internal Audit Standards

Internal Audit Standards; Dittenhofer (2001) ; Cohen and Savag (2010)

\subsection{Data collection}

After the generation of an initial set of items and required purification, the questionnaire was pre-tested by three internal auditors and two professors of accounting to improve comprehensibility of statements. There were two parts to the survey. Part A comprised of participant's demographic and academic backgrounds. In Part B, the participants were asked to rate their level of agreement for each of the 24 statements on a five-point Likert scale ranging from 1 "strongly disagree to strongly agree" to 5 "strongly agree".

Respondents from 225 initial public offering firms in Tunisia were contacted to fill the questionnaire.

\begin{tabular}{llc}
\hline Demographic variables & Frequency & Percentage \\
\hline Academic qualification & & 59.45 \\
License & 88 & 39.18 \\
Master's degree & 58 & 1.35 \\
PhD & 2 & 68.91 \\
Professional qualification & & 102
\end{tabular}

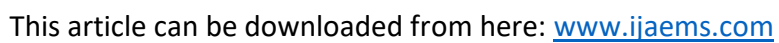

(C)2021 The Author(s). Published by Infogain Publication.

This work is licensed under a Creative Commons Attribution 4.0 License. http://creativecommons.org/licenses/by/4.0/
Questionnaires were distributed to the chief internal auditors between September and December 2020. In total, we obtained 148 completed questionnaires giving a response rate of $65.77 \%$. The profile of the participants is showed in table 2 .

Unlike the approach proposed by Churchill (1979), we proceeded with a single data collection for the development of our scale. However, we randomly selected $50 \%$ of our sample for the exploratory analysis and then used the other $50 \%$ of the sample for the confirmatory analysis.

\section{Table2: Profile of participants}




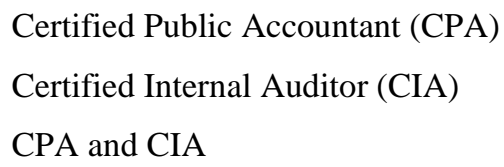

Experience

$\begin{array}{ll}1-5 \text { years } & 36 \\ 6-10 \text { years } & 48 \\ \text { More than } 10 \text { years } & 64\end{array}$

Number of internal auditors in the internal auditing department
28

14

4

36

48

64

10

16

2
18.91

9.45

2.70

24.32

81.08

6.75

10.81

1.35

Gender
114
34
Male
34
77.02
Female
22.97

\section{DATA ANALYSIS AND RESULTS}

\subsection{Exploratory factor analysis}

After data collection, the authors conducted an exploratory analysis with the statistical software IBM SPSS 18 to determine the reliability of the multi-dimensional scale for the measurement of internal auditing effectiveness.

The first step of this procedure consists of observing the inter-item correlations for the purpose of evaluating the correlation between the items and eliminating those for which no correlation was greater than or equal to 0.3 . This step made us eliminate two items EAI 3 and EAI 8. In the second step in this procedure, we used a principal component analysis (PCA) with Varimax rotation to verify the dimensional structure of the scale. The rotated component matrix was examined to see the extracted factors and was labelled accordingly. Varimax rotation was carried out to identify the potential factor structure. In this regard, the minimum factor loading criteria were set to 0.50 .

Before performing the CPA analysis, the data were evaluated in terms of the factorability of the correlation matrix. For this, we calculated the Kaiser Meyer-Olkin (KMO) index to assess the relevance of the CPA and performed the Bartlett's test of sphericity which determines whether the correlation matrix has significant correlations among some of its components. The KMO index is 0.855 , which is higher than the 0.5 limit (Kaiser \& Rice, 1974). As a result, the items can be factored. Then we ran the Bartlett's test of sphericity, which generates a significant value of 0.000 . So, the correlation matrix is not a unit matrix, the items do have some correlation. As a consequence, factoring is possible.

Initially, the PCA gives a 4-dimensional factor structure which restores $67.765 \%$ of the total variance and indicates that all items have communalities greater than 0.5 . However, we deleted the item EAI 24 because it was correlated to more than one factor. Then a second iteration was carried out thus giving a factorial structure with 4 dimensions. The eigenvalues associated with all of the identified dimensions explain $67.997 \%$ of the total variance. All of the items have a high quality of representation $(>0.50)$. At this point, we have eliminated item EAI 4, which has a factor contribution of less than 0.5 .

From the 20 remaining items, we proceeded to a third iteration. The PCA gave us a 4-dimensional factor structure which restores $68.714 \%$ of the total variance and shows that all the items have communities higher than 0.5 . All of the items have a factor weight greater than 0.5 . However, we decided to delete two items, EAI 12 and EAI 17 , because they form a dimension on their own.

Subsequently, three factors and 18 items were extracted, namely: Internal audit process (4 items); output of internal audit (4 items); and impact of internal audit (10 items). All items loaded in these three factors were ranged between 0.516 and 0.807 and thus proven to have well-defined factor structure. The three factors have been extracted with Eigen value greater than 1.0, explaining 65.4 per cent of total variance. 
The Cronbach's $\alpha$ (CA) coefficient was 0.940, 0793, and 0.710 respectively for factor 1 , factor 2 and factor 3 .
Nunnally (1978) has recommended that the minimum level of acceptance should be 0.70 and above.

Table3: Results of the exploratory factor analysis

\begin{tabular}{|c|c|c|c|c|c|}
\hline \multirow[t]{2}{*}{ Code } & \multirow[t]{2}{*}{ Items } & \multirow[t]{2}{*}{ Commun-alities } & \multicolumn{3}{|c|}{ Extracted Factors } \\
\hline & & & $\begin{array}{c}\text { Factor } \\
1\end{array}$ & $\begin{array}{c}\text { Factor } \\
2\end{array}$ & $\begin{array}{c}\text { Factor } \\
3\end{array}$ \\
\hline EAI 1 & $\begin{array}{l}\text { Internal audit (IA) is performed in accordance } \\
\text { with international standards for the professional } \\
\text { practice of internal auditing. }\end{array}$ & 0.793 & & 0.831 & \\
\hline EAI 2 & $\begin{array}{l}\text { IA is performed in accordance with the } \\
\text { recommended guidance. }\end{array}$ & 0.638 & & 0.761 & \\
\hline EAI 5 & $\begin{array}{l}\text { The chief internal auditor (CIA) develops a risk- } \\
\text { based audit plan. }\end{array}$ & 0.714 & & 0.536 & \\
\hline EAI 6 & $\begin{array}{l}\text { The CIA performs almost all of the annual internal } \\
\text { audit plan. }\end{array}$ & 0.516 & & & 0.652 \\
\hline EAI 7 & $\begin{array}{l}\text { The CIA ensures that recommendations of internal } \\
\text { auditing provide corrective actions for the problems } \\
\text { identified. }\end{array}$ & 0.551 & & 0.714 & \\
\hline EAI 9 & $\begin{array}{l}\text { The CIA verifies regularly the level of } \\
\text { implementation of internal audit recommendations } \\
\text { by management. }\end{array}$ & 0.612 & & & 0.691 \\
\hline $\begin{array}{l}\text { EAI } \\
10\end{array}$ & $\begin{array}{l}\text { The CIA communicates the results of internal audit } \\
\text { to senior management and board of directors in a } \\
\text { timely manner. }\end{array}$ & 0.570 & & & 0.594 \\
\hline $\begin{array}{l}\text { EAI } \\
11\end{array}$ & $\begin{array}{l}\text { Time delay between the end of the mission and the } \\
\text { dissemination of the report is short. }\end{array}$ & 0.610 & & & 0.765 \\
\hline $\begin{array}{l}\text { EAI } \\
13\end{array}$ & $\begin{array}{l}\text { IA assesses the effectiveness of the system of } \\
\text { control related to the reliability and integrity of } \\
\text { financial and operational information. }\end{array}$ & 0.775 & 0.812 & & \\
\hline $\begin{array}{l}\text { EAI } \\
14\end{array}$ & $\begin{array}{l}\text { IA assesses the effectiveness of the system of } \\
\text { control related to the effectiveness and efficiency of } \\
\text { operations and programs. }\end{array}$ & 0.716 & 0.781 & & \\
\hline $\begin{array}{l}\text { EAI } \\
15\end{array}$ & $\begin{array}{l}\text { IA assesses the effectiveness of the system of } \\
\text { control related to the asset protection. }\end{array}$ & 0.743 & 0.806 & & \\
\hline $\begin{array}{l}\text { EAI } \\
16\end{array}$ & $\begin{array}{l}\text { IA assesses the effectiveness of the system of } \\
\text { control related to compliance with laws. } \\
\text { Regulations, procedures and contracts. }\end{array}$ & 0.807 & 0.867 & & \\
\hline $\begin{array}{l}\text { EAI } \\
18\end{array}$ & $\begin{array}{l}\text { IA ensures that the organization's objectives are } \\
\text { consistent with the internal audit missions. }\end{array}$ & 0.629 & 0.705 & & \\
\hline $\begin{array}{l}\text { EAI } \\
19\end{array}$ & $\begin{array}{l}\text { IA ensures that the risk treatment methods are } \\
\text { appropriate and in line with the risk appetite of the } \\
\text { organization. }\end{array}$ & 0.704 & 0.716 & & \\
\hline $\begin{array}{l}\text { EAI } \\
20\end{array}$ & $\begin{array}{l}\text { IA assesses the possible frauds and how risk of } \\
\text { fraud is managed by the organization. }\end{array}$ & 0.584 & 0.741 & & \\
\hline
\end{tabular}




\begin{tabular}{|l|l|l|l|l|l|}
\hline $\begin{array}{l}\text { EAI } \\
21\end{array}$ & $\begin{array}{l}\text { IA contributes to improving the risk management } \\
\text { process. }\end{array}$ & 0.611 & 0.711 & & \\
\hline $\begin{array}{l}\text { EAI } \\
22\end{array}$ & $\begin{array}{l}\text { IA assesses the design, implementation and } \\
\text { effectiveness of the organization's programs and } \\
\text { activities related to ethics. }\end{array}$ & 0.639 & 0.627 & & \\
\hline $\begin{array}{l}\text { EAI } \\
23\end{array}$ & $\begin{array}{l}\text { IA assesses whether the organization's information } \\
\text { systems supports the organization's strategy and } \\
\text { goals. }\end{array}$ & 0.579 & 0.594 & & \\
\hline Eign values & & 6.159 & 3.060 & 2.572 \\
\hline$\%$ of variance explained & & 34.21 & 16.99 & 14.2 \\
\hline Cronbach's alpha & & 0.940 & 0.793 & 0.710 \\
\hline
\end{tabular}

\subsection{Confirmatory factor analysis}

In a second step, we performed a confirmatory factor analysis to test the fit and factor structure of the measurement model identified by the exploratory analysis. SMART PLS 3.2.6 was used to verify the convergent and discriminant validity of the measuring instrument. We chose to use the PLS method because it is particularly suitable for small sample sizes.

The first confirmatory factor analysis led to the removal of the two items EAI 11 and EAI 20, the factor loadings of which were lower than 0.7 . We, therefore, re-specified our model with the remaining 16 items and verified the validity of this new model by performing a second confirmatory factor analysis.

The results presented in table 4 confirm the good convergent validity of the scale (Hair et al., 2006) as all the items have factor loadings greater than 0.7 and Cronbach's $\alpha$ coefficients exceeded the 0.7 threshold. Hence, all values of Composite Reliability (CR) were between 0.846 and 0.949 , showing that measures in the study were reliable. Table 4 also shows that Average Variance Extracted (AVE) values of each dimension were over 0.50 while being less than CRs.

The results also confirm the discriminant validity of the internal audit effectiveness scale as the square root of the AVE for each dimension is greater than the correlations of that dimension with each of the other three (Fornell \& Larcker, 1981; Hair et al., 2006). The obtained results indicated a good adjustment of the model since the SRMR is 0.089 which is higher than its acceptance threshold of 0.08 ; the chi-square is equal to 247 ( $p<0.01$ ) and the GoF is 0.519 which is greater than the threshold 0.30 (Tenenhaus et al., 2004). The scale reliability, calculated using Joreskog's Rho, provides satisfactory results. The coefficients for the internal audit process, the internal audit outputs and the internal audit impact were 0.872. 0.846. and 0.949 respectively.

Table 4: Verification of convergent and discriminant validities of constructs

\begin{tabular}{|l|l|l|l|l|l|l|}
\hline Construct & \multicolumn{3}{|c|}{ Convergent validity } & \multicolumn{2}{c|}{ Discriminant validity : correlation matrix } \\
\hline & Cronbach's $\alpha$ & CRs & AVEs & $\begin{array}{c}\text { Impact of } \\
\text { internal } \\
\text { audit }\end{array}$ & $\begin{array}{c}\text { Internal } \\
\text { audit } \\
\text { outputs }\end{array}$ & $\begin{array}{l}\text { Internal } \\
\text { audit } \\
\text { process }\end{array}$ \\
\hline Impact of internal audit & 0.939 & 0.949 & 0.674 & $\mathbf{0 . 8 2 1}$ & & \\
\hline Internal audit outputs & 0.728 & 0.846 & 0.647 & 0.613 & $\mathbf{0 . 8 0 4}$ & \\
\hline Internal audit process & 0.809 & 0.872 & 0.632 & 0.664 & 0.491 & $\mathbf{0 . 7 9 5}$ \\
\hline
\end{tabular}

To sum up, confirmatory analysis reveals that the internal auditing effectiveness scale is composed of three dimensions. The first dimension is the internal audit process including four items, the second dimension refers to the output of the internal audit including three items and the third dimension corresponds to the impact of the internal audit including nine items. The 16 items of the 
internal auditing effectiveness scale are presented in Table

5.

Table 5: List of 16 items of the final measurement scale of the effectiveness of internal audit

\begin{tabular}{|c|c|c|}
\hline Dimensions & Code & Items \\
\hline \multirow[t]{4}{*}{$\begin{array}{l}\text { Internal audit } \\
\text { process }\end{array}$} & EAI 1 & $\begin{array}{l}\text { Internal audit is carried out in accordance with international } \\
\text { standards for internal auditing. }\end{array}$ \\
\hline & EAI 2 & $\begin{array}{l}\text { The internal audit is carried out in accordance with the Practical } \\
\text { Terms of Application. }\end{array}$ \\
\hline & EAI 5 & The Head of internal audit (HIA) develops a risk-based audit plan. \\
\hline & EAI 6 & The HIA carries out almost all of the annual internal audit plan. \\
\hline \multirow[t]{3}{*}{$\begin{array}{l}\text { Internal audit } \\
\text { outputs }\end{array}$} & EAI 7 & $\begin{array}{l}\text { The HIA ensures that the recommendations formulated provide } \\
\text { corrective solutions for the problems identified. }\end{array}$ \\
\hline & EAI 9 & $\begin{array}{l}\text { The HIA continuously checks the level of consideration of internal } \\
\text { audit recommendations by management. }\end{array}$ \\
\hline & EAI 10 & $\begin{array}{l}\text { The HIA communicates the results of the mission to senior } \\
\text { management and the board of directors in a timely manner. }\end{array}$ \\
\hline \multirow[t]{9}{*}{$\begin{array}{l}\text { Internal audit } \\
\text { process }\end{array}$} & EAI 13 & $\begin{array}{l}\text { Internal audit assesses the effectiveness of the system for controlling } \\
\text { the reliability and integrity of financial and operational information. }\end{array}$ \\
\hline & EAI 14 & $\begin{array}{l}\text { Internal audit assesses the effectiveness of the control system for the } \\
\text { effectiveness and efficiency of operations and programs. }\end{array}$ \\
\hline & EAI 15 & $\begin{array}{l}\text { Internal audit assesses the effectiveness of the asset protection } \\
\text { control system. }\end{array}$ \\
\hline & EAI 16 & $\begin{array}{l}\text { Internal audit assesses the effectiveness of the system for monitoring } \\
\text { compliance with laws, regulations, procedures, and contracts. }\end{array}$ \\
\hline & EAI 18 & $\begin{array}{l}\text { Internal audit ensures that the organization's objectives are consistent } \\
\text { with its mission. }\end{array}$ \\
\hline & EAI 19 & $\begin{array}{l}\text { Internal audit ensures that the risk treatment methods used are } \\
\text { appropriate and in line with the risk appetite of the organization. }\end{array}$ \\
\hline & EAI 21 & Internal audit contributes to improving the risk management process. \\
\hline & EAI 22 & $\begin{array}{l}\text { Internal audit assesses the design, implementation, and effectiveness } \\
\text { of the organization's ethics-related programs and activities. }\end{array}$ \\
\hline & EAI 23 & $\begin{array}{l}\text { Internal audit assesses whether the governance of the organization's } \\
\text { information systems supports the organization's strategy and goals. }\end{array}$ \\
\hline
\end{tabular}

\section{CONCLUSION}

The present research aims to construct a scale of internal auditing effectiveness in Tunisia. Our methodology is based on the approach of Churchill (1979). The first step of this study is to generate items for IAE through literature review and interviews with nine chief internal auditors. The second step is in the conduct of an exploratory factor analysis which revealed three factors, namely internal audit process, output of internal audit and impact of internal audit. The Confirmatory factor analysis demonstrated a valid and reliable scale for measuring IAE. This scale is consists of 16 items divided into three dimensions. The first dimension includes 4 items dealing with the internal audit process. The second dimension is composed of 3 items informing on the output of the internal audit and the last dimension includes 9 items reflecting the impact of the internal audit on the process of internal control, risk management and corporate governance.

Our study represents a first contribution to the construction of a reliable and valid scale for measuring IAE in an emerging context, like Tunisia. The scale can be used by managers, audit committees and external auditors as a tool for measuring and analysing the level of internal auditing effectiveness in the organization. Thus, the scale can be used to explore the strongest areas of internal auditing, 
which will allow chief internal auditors to improve the effectiveness of their function. The major limitation of this research is the small sample size, which may ultimately limit paper generalizability of the results. Therefore, future researches shall increase the sample size and can test the scale and its validity in other countries to enrich the results obtained.

\section{REFERENCES}

[1] Agbejule. A. \& Jokipii, A. (2009). Strategy. control activities. monitoring and effectiveness. Managerial Auditing Journal, 24 (6), 500-522.

[2] Alazzabi, W.Y.E., Mustafa, H. \& Karage, A.I. (2020). Risk management, top management support, internal audit activities and fraud mitigation. Journal of Financial Crime, https://doi.org/10.1108/JFC-11-2019-0147

[3] Albawwat, I.E., Al-hajaia, M.E. \& Al frijat, Y.S. (2021).The Relationship Between Internal Auditors' Personality Traits, Internal Audit Effectiveness, and Financial Reporting Quality: Empirical Evidence from Jordan. Journal of Asian Finance, Economics and Business, 8(4), 797-808.

[4] Al-twaijry, A. A. M., Brierley, J. A. \& Gwilliam, D. R. (2003). The development of internal audit in Saudi Arabia: an institutional theory perspective. Critical Perspective on Accounting, 14 (5), 507-531.

[5] Alzeban, A. (2020). The relationship between the audit committee, internal audit and firm performance. Journal of Applied Accounting Research, 21 (3), 437-454.

[6] Alzeban, A. (2021). Internal audit findings, audit committees, and firm performance evidence from UK. AsiaPacific Journal of Accounting \& Economics, https://doi.org/10.1080/16081625.2021.1908153

[7] Alzoubi, E. (2019). Audit committee. internal audit function and earnings management: evidence from Jordan. Meditari Accountancy Research, 27 (1), 72-90.

[8] Anderson, U. (1983). Quality Assurance for Internal Auditing. Institute of Internal Auditors: Altamonte Springs.

[9] Arena, M. \& Azzone, G. (2009). Identifying organizational drivers of internal audit effectiveness. International Journal of Auditing, 13 (1), 43-60.

[10] Balzan, L. \& Baldacchino, P.J. (2007). Benchmarking in Maltese internal audit units. Benchmarking: An International Journal, 14 (6), 750-767.

[11] Botha, L. \& Wilkinson, N. (2019). A framework for the evaluation of the perceived value added by internal auditing. Meditari Accountancy Research, 28 (3), 413-434.

[12] Carcello, J. V., Hermanson, D. R. \& Raghunandan, K. (2005). Changes in internal auditing during the time of the major US accounting scandals. International Journal of Auditing, 9 (2), 117-127.

[13] Churchill, G. A. (1979). A paradigm for developing better measures of marketing constructs. Journal of Marketing Research, 16, 64-73.

[14] Coetzee, P.P. (2016). Contribution of internal auditing to risk management: perceptions of public sector senior management. International Journal of Public Sector Management, 29 (4), 348-364.

[15] Cohen, A. \& Sayag, G. (2010). The effectiveness of internal auditing: an empirical examination of its determinants in Israeli organizations. Australian Accounting Review, 20 (3), 296-307.

[16] Cohen, J., Krishnamoorthy, G. \& Wright, A. (2004). The corporate governance mosaic and financial reporting quality. Journal of Accounting Literature, 23, 87-152.

[17] Coram, P., Ferguson, C. \& Moroney, R. (2008). Internal audit, alternative audit structures and the level of misappropriation of assets fraud. Accounting and Finance, 48 (4), 1-17.

[18] Dezoort, T. \& Harrison, P. (2008). An Evaluation of Internal Auditor Responsibility for Fraud Detection. The Institute of Internal Auditors Research Foundation.

[19] Dittenhofer, M. (2001). Internal audit effectiveness: an expansion of present methods. Managerial Auditing Journal, 16 (8), 443-450.

[20] Eden, D. \& Moriah, L. (1996). Impact of Internal Auditing on Branch Bank Performance: A Field Experiment. Organizational Behavior and Human Decision Processes, 68 (3), 262-271.

[21] Erasmus, L. \& Coetzee, P. (2018). Drivers of stakeholders' view of internal audit effectiveness: Management versus audit committee. Managerial Auditing Journal, 33 (1), 90114.

[22] Farkas, M., Hirsch, R. \& Kokina, J. (2019). Internal auditor communications: an experimental investigation of managerial perceptions. Managerial Auditing Journal, 34 (4), 462-485.

[23] Fornell, C. \& Larcker, D.F. (1981). Structural equation models with unobservable variables and measurement error: Algebra and statistics. Journal of Marketing Research, 18 (3), 382-388.

[24] Frigo, M. (2002). A Balanced Scorecard Framework for Internal Auditing Departments. The Institute of Internal Auditors Research Foundation: Florida.

[25] Garcia, L.S., Barbadillo, E.R. \& Orta Perez, M. (2012). Audit committee and internal audit and the quality of earnings: empirical evidence from Spanish companies. Journal of Management and Governance, 16 (2), 305-331.

[26] Ghaleb, B.A.A., Kamardin, H. \& Al-Qadasi, A.A. (2020).Internal audit function and real earnings management practices in an emerging market. Meditari Accountancy Research, 28 (6), 1209-1230.

[27] Glazer, A.S. \& Jaenike, H.R. (1980). A Framework for Evaluating an Internal Audit Function. Foundation for Audit Ability Research and Education.

[28] Gramling, A., Maletta, A., Schneider, A. \& Church, B.(2004). The role of the internal audit function in corporate governance: A synthesis of the extant internal auditing literature and directions for future research. Journal of Accounting Literature, 23 (1), 193-244.

[29] Gras-Gil, E., Hernandez, S. \& De Lema, D. (2012). Internal audit and financial reporting in the Spanish banking industry. Managerial Auditing Journal, 27 (8), 728-753. 
[30] Hair, J., Black, W., Babin, B., Anderson, R. \& Tatham, R. (2006). Multivariate analysis. Upper Saddle River: Pearson Prentice Hall.

[31] Hazaea, S., Tabash, M., Khatib, S., Zhu, J. \& Al-Kuhali, A. (2020). The Impact of Internal Audit Quality on Financial Performance of Yemeni Commercial Banks: An Empirical Investigation. Journal of Asian Finance, Economics and Business, 7 (11), 867-875.

[32] Hazami-Ammar, S. (2019). Internal auditors' perceptions of the function's ability to investigate fraud. Journal of Applied Accounting Research, 20 (2), 134-153.

[33] Héroux, S. \& Fortin, A. (2013). The Internal Audit Function in Information Technology Governance: A Holistic Perspective. Journal Of Information Systems, 27 (1), 189217.

[34] Institute of Internal Auditors (IIA). (1999). Definition of Internal Auditing. Institute of Internal Auditors: Altamonte Springs.

[35] Ismael, H. \& Roberts, C. (2018). Factors affecting the voluntary use of internal audit: evidence from the UK. Managerial Auditing Journal, 33 (3), 288-317.

[36] Jiang, L., Messier, Jr. W.F. \& Wood, D.(2020). The Association between Internal Audit Operations-Related Servicesand Firm Operating Performance. Auditing: A Journal of Practice \& Theory, 39 (1), 101-124.

[37] Kabuye, F., Nkundabanyanga, S. K., Opiso, J. \& Nakabuye, Z. (2017). Internal audit organisational status. competencies. activities and fraud management in the financial services sector. Managerial Auditing Journal, 32 (9), 924-944.

[38] Kaiser, H.F. \& Rice, J. (1974). Little Jiffy Mark IV. Educational and Psychological Measurement, 34 (1), 111117.

[39] Lampe, J. \& Sutton, S. (1994). Developing Productivity in Quality Measurements Systems for Internal Audit Departments. The Institute of Internal Auditors Research Foundation.

[40] Law, P. (2011). Corporate governance and no fraud occurrence in organizations: Hong Kong evidence. Managerial Auditing Journal, 26 (6), 501-518.

[41] Mihret, D. G., James, K. \& Mula, J. M. (2010). Antecedents and organizational performance implications of internal audit effectiveness: some propositions and research agenda. Pacific Accounting Review, 22 (3), 224-252.

[42] Mohammadzadeh, V., Kangarlouei, S. J. \& Motavassel, M. (2012). Evaluation of internal audit effectiveness in Tehran Stock Exchange (TSE). Research Journal of Business Management and Accounting, 1 (2), 19-24.

[43] Naheem, M.A. (2016). Internal audit function \& AML compliance: the globalisation of the internal audit function. Journal of Money Laundering Control, 19 (4), 459-469.

[44] Nunnally, J. C. \& Bernstein, I. H. (1994). Psychometric theory. New York. McGraw-Hill. Inc.

[45] Nunnally, J. C. (1978). Psychometric theory. New-York. McGraw-Hill: 2nd edition.

[46] Octavia, E. (2013). The effects of implementation on internal audit and good corporate governance in corporate performance. Journal of Global Business and Economics, 6 (1), 77-87.
[47] Omar, N. \& Abu Bakar, K. (2012). Fraud Prevention Mechanisms of Malaysian Government-Linked Companies: An Assessment of Existence and Effectiveness. Journal of Modern Accounting and Auditing, 8 (1), 15-31.

[48] Oussii, A. \& Taktak, N. (2018). The impact of internal audit function characteristics on internal control quality. Managerial Auditing Journal, 33 (5), 450-469.

[49] Prawitt, D. F.,Smith, J.L. \& Wood, D.L. (2009). Internal audit quality and earning management. The Accounting Review, 84 (4), 1255-1280.

[50] Radu, M. (2012). Corporate governance. internal audit and environmental audit - the performance tools in Romanian companies. Accounting and Management Information Systems, 11 (1), 112-130.

[51] Regoliosi, C. \& D'eri, A. (2014). Good corporate governance and the quality of internal auditing departments in Italian listed firms. An exploratory investigation in Italian listed firms. Journal of Management and Governance, 18 (3), 891-920.

[52] Salehi, M., Arianpoor, A. \& Salehi, F. (2013). Investigating the Effect of Internal Audit on the Performance of Private Banks' System. Journal of Accounting Business \& Management, 20 (1), 46-58.

[53] Salierno, D. (2000). The right measures. The Internal Auditor, 57 (1), 41-46.

[54] Sarens, G. (2009). Internal auditing research: Where are we going? Editorial. International. Journal of Auditing, 1, 1-7.

[55] Sarens, G. \& De Beelde, I. (2006). Internal auditors' perception about their role in risk management: A comparison between US and Belgian companies. Managerial Auditing Journal, 21(1), 63-80.

[56] Soh, D.S. \& Bennie, N.M. (2011). The internal audit function: Perceptions of internal audit roles. Effectiveness. and evaluation. Managerial Auditing Journal, 26 (7), 605622.

[57] Spira, L. F. \& Page, M. (2003). Risk management: the reinvention of internal control and the changing role of internal audit. Accounting. Auditing \& Accountability Journal, 16 (4), 640-661.

[58] Tenenhaus, M., Amato, S. \& Esposito Vinzi, V. (2004). A global goodness-of-fit index for PLS structural equation modeling. Proceedings of the XLII SIS Scientific Meeting. Padova.

[59] Vadasi, C., Bekiaris, M. \& Andrikopoulos, A. (2019). Corporate governance and internal audit: an institutional theory perspective. Corporate Governance, 20 (1), 175-190.

[60] Ziegenfus, D.E. (2000a). Developing an internal auditing department balanced scorecard. Managerial Auditing Journal, 15 (1/2), 12-19.

[61] Ziegenfuss, D. E. (2000b). Measuring performance. The Internal Auditor, 57 (1), 36-40. 